\title{
Characterization of pericarp fractions of yellow passion fruit: density, yield of flour, color, pectin content and degree of esterification
}

\author{
Simone Vilela TALMA ${ }^{1}$, Suelen Alvarenga REGIS ${ }^{1}$, Patrícia Rodrigues FERREIRA ${ }^{1}$, Caroline MELLINGER-SILVA ${ }^{2}$, \\ Eder Dutra de RESENDE ${ }^{1 *}$
}

\begin{abstract}
The pericarp of passion fruit can be processed to be used as a new ingredient in the food industry, or as source of pectin. Pericarp samples were taken with a $5 \mathrm{~mm}$ cylindrical metal probe to measure the apparent density. Pericarp fractions of eighty fruits at three maturation stages were dried and their flours were quantified and evaluated by instrumental color. The pectin was extracted and its degree of esterification (DE) was quantified. The yield of flour of epicarp and mesocarp reached 3.4\% and $4.6 \%$ (dry basis) at different maturation stages of passion fruit, respectively. The content of pectin was higher in mesocarp flour, also, its DE increased deeply with the fruit maturation. The mesocarp with the lower density can be separated from the epicarp in a water flow system, which allows the production of clearer flour with the highest content of pectin and the highest DE in ripe fruits.
\end{abstract}

Keywords: Passiflora edulis; co-products; rind processing; waste; juice industry.

Practical Application: The industrialization of passion fruit produces a huge amount of rinds that can be processed to be used as a new ingredient in the food industry due to its high content of pectin, which confers rheological properties such as stabilizing, thickening and gelling during food processing. The rind of passion fruit is divided into epicarp, mesocarp and endocarp. The separation and processing of these materials can enable to produce better quality mesocarp flour.

\section{Introduction}

Brazil is the major world producer and consumer of yellow passion fruit (Passiflora edulis Sims), with a production of 703,489 metric tons in 2016. The northeast region of Brazil is the major producer, covering around $70 \%$ of the crop (Instituto Brasileiro de Geografia e Estatística, 2017). The industrialization of passion fruit to obtain pulp generates around 54 thousand tons of waste per year in Colombia, such as seeds and rinds (López-Vargas et al., 2013). In Brazil, approximately $40 \%$ of the production is processed by juice industries (Pimentel et al., 2009). The amount of rind can reach $50.7 \%$ of the mass of ripe fruit, or 79.2\% of the green fruit (Oliveira \& Resende, 2012).

New technologies that aggregate values to this raw material wasted by industries may have great economical goal, as well as to ensure the mitigation of the environmental liabilities generated by the industries (Nascimento et al., 2013).

There are several health benefits associated to the consumption of the soluble fiber from rind flour of passion fruit: slower bowel movements, which raises food satiety, lowering glucose intake and blood cholesterol levels, as well as the contribution in controlling chronic diseases related to cancer or diabetes (Tseng \& Zhao, 2013; Quirós-Sauceda et al., 2014; Figueiredo et al., 2016; Marques et al., 2016).

Furthermore, it presents functional properties for human health, especially in the control of obesity, diabetes and dyslipidemia (Smith et al., 2012; Araújo et al., 2017). Also, it may be an alternative source of pectin, since the commercial pectin available is extracted from apple pomace and citrus fruit rind (Vasco-Correa \& Zapata, 2017).

The rind of passion fruit is a promising by product applicable to produce flour, that can be used to enrich foods due to its high content of pectin, which confers rheological properties such as stabilizing, thickening and gelling during food processing (Canteri et al., 2010a).

In Brazil, the rind flour of passion fruit is produced in small commercial scale, after the drying of the crude rind of fruit, which includes the most external yellow part (epicarp), the white pectin-rich fraction in the middle of the peel (mesocarp), and the inner part, around the seed (endocarp) (Canteri et al., 2010b). It is used by consumers as a fiber-rich supplement flour that is added to the meal, aiming to control diabetes, dyslipidemia and cholesterol (López-Vargas et al., 2014; Claro et al., 2018). However, due to the presence of the epicarp in the crude rind, the flour of the rind becomes brownish and with undesirable flavor and taste. After removing the epicarp from the crude rind, the pure mesocarp flour presents better appearance and absence of bitterness, favoring its application as an ingredient in food products (Oliveira \& Resende, 2012). The use of this flour has been proposed for several kinds of foods, including

${ }^{1}$ Laboratório de Tecnologia de Alimentos, Universidade Estadual do Norte Fluminense Darcy Ribeiro - UENF, Campos dos Goytacazes, RJ, Brasil

${ }^{2}$ Embrapa Agroindústria de Alimentos, Rio de Janeiro, RJ, Brasil

*Corresponding author: eresende@uenf.br 
meat-based products (López-Vargas et al., 2014), yoghurts (Espírito Santo et al., 2012) and honey bread (Conti-Silva \& Roncari, 2015).

The passion fruit rind is an alternative pectin source to apple pomace or citrus peel; however, the type of acid and its concentration used for pectin extraction can affect the molecular characteristics of pectin and its technological application. In general, the best rheological properties and extraction yield are achieved with weak organic acid or strong mineral acid diluted, or tempered with the use of a conjugate base of a weak acid, such as sodium citrate (Yapo, 2009; Sundarraj \& Ranganathan, 2017).

In view of the large amount of passion fruit rinds wasted by industries, along with the possibility of applying new technologies to the development of co-products from this material, this study aimed at quantifying the mass proportion of epicarp, mesocarp and endocarp of the fruits in different maturation stages that are normally processed by industries. The flour of these materials were evaluated in terms of color pattern, content of pectin and degree of esterification, in addition to having the flour yield quantified, based on a mass balance. The apparent density of the pericarp fractions was also evaluated, aiming to apply the separation process of the mesocarp and epicarp in a water floating system.

\section{Materials and methods}

\subsection{Characterization of the raw material}

The passion fruits (Passiflora edulis Sims) were harvested in a commercial orchard located in São José de Ubá (RJ, Brazil). The number of fruits selected was 80 , at three maturation stages (clear green peel, intermediate and ripe fruits), standardized with $10.3-10.5 \mathrm{~cm}$ length $(\mathrm{L})$ and $8.2-8.4 \mathrm{~cm}$ width $(\mathrm{W})$, ratio $\mathrm{L} / \mathrm{W}=1.3$. The fruits were washed under tap water and sanitized with $0.1 \mathrm{~mL} \mathrm{~L}^{-1}$ chlorine solution for $15 \mathrm{~min}$., dried with paper towel and stored at $10{ }^{\circ} \mathrm{C}$ and $90 \%$ relative humidity until processing.

The peel color was recorded using a Spectrophotometer (Hunterlab MiniScan XE Plus, USA) calibrated to a standard white and black reflective plate. A D65 illuminant and a $10^{\circ}$ standard observer were employed. The measurements were taken at two equidistant points in the equatorial region of sun-exposed and non-exposed side of the fruit. The proportion of yellow peel color was determined in relation to the full change of Hunter $b$ parameter, in each maturation stage (Silva et al., 2008).

\subsection{Apparent density of pericarp fractions}

Pericarp samples from clear green peel color fruits were obtained with a cylindrical metal probe, measuring $5 \mathrm{~mm}$ diameter, in the radial direction of the fruit rind, taking off samples at three distinct parts: epicarp (external pellicle), mesocarp (internal part of the rind) and interface between epicarp and mesocarp. The fractions of each component of the rind were cut with a stainless steel stylet that allowed the careful separation of each fraction along the radial position of the rind. The methodology of density determination was based on the volumetric balloon method (Gubiani et al., 2006), with adaptations, using ethyl alcohol $\left(92^{\circ} \mathrm{GL}\right)$ at $24^{\circ} \mathrm{C}$ as a standard reference for measurements, with eight replicates. The apparent density measurements of the samples were obtained according to Equation 1.

$\rho_{\mathrm{p}}=\frac{\mathrm{Mbs}-\mathrm{Mb}}{\mathrm{V}-\frac{\mathrm{Mbsl}-\mathrm{Mbs}}{\rho_{\mathrm{a}}}}$

In which $\rho_{\mathrm{p}}=$ Apparent density of the particles $\left(\mathrm{kg} \mathrm{m}^{-3}\right) ; M b=$ Mass of the balloon (kg); Mbs = Mass of balloon plus the sample (kg); $M b s l=$ Mass of the balloon plus the samples plus the liquid $\left(\mathrm{m}^{3}\right) ; \rho \mathrm{a}=$ Density of the ethyl alcohol $\left(\mathrm{kg} \mathrm{m}^{-3}\right)$. The density of particles was measured with their original moisture content, after fast immersion in the flask.

\subsection{Fruit processing}

The fruits were weighted in an analytical balance (Gehaca, BG 2000, Brazil) and processed with a peeling fruit machine (Spolu, SPL-008, Brazil) adjusted to remove $1 \mathrm{~mm}$ of epicarp on fruit surface. Each fruit was cut in equatorial position to remove and quantify the pulp containing seeds and arils. The endocarp in the inner rind cavity was removed with a spatula and weighted, which enabled the measurement of the mesocarp mass. The proportion of each component was standardized to $100 \mathrm{~g}$ fruit. The rind components were analyzed by moisture content (Association of Official Analytical Chemists, 1990), packed in hermetic flask and stored in freezer at $-20^{\circ} \mathrm{C}$ until processing.

The rind components were processed on a thin layer in a tray dryer (Pardal, Brazil) with forced air at $60^{\circ} \mathrm{C}$ for $20 \mathrm{~h}$. The dried material was processed in an analytical mill (Quimis, Brazil) and then it was standardized in a $0.297 \mathrm{~mm}$ sieve (50 Mesh). The sample of flour was composed by rind components of 8 fruits, with 10 replicates for each maturation stage. Regarding the endocarp flour, each sample was taken from 16 fruits due to the small amount of material obtained.

\subsection{Determination of the color and yield of flour}

The calculation of the yield of flour for the rind fractions in relation to the fruit mass was based on a mass balance, taking into account the proportion of each component of the rind and its content of dry matter (Association of Official Analytical Chemists, 1990), also assuming a final content of dry matter of $90 \%$ (Equation 2).

$\mathrm{Y}_{\mathrm{f}}=\left(\frac{\mathrm{F}_{\text {comp }} * \mathrm{X}_{\mathrm{dm}}}{\mathrm{DM}_{\mathrm{f}}}\right) * 100$

In which $\mathrm{Y}_{\mathrm{f}}=$ Yield of flour for the rind components, $\%$ (g $100 \mathrm{~g}^{-1}$ fruit); $\mathrm{F}_{\text {comp }}=$ Proportion of the rind component ( $\mathrm{g} 100 \mathrm{~g}^{-1}$ fruit); $\mathrm{X}_{\mathrm{dm}}=$ Content of dry matter of each component

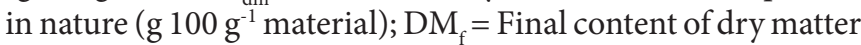

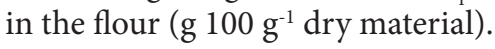

Color measurements of the flour were done on $10 \mathrm{~g}$ of flour, which was maintained inside a crystal cube covered with a black opaque cup. Records were applied after each rotational movement of $45^{\circ}$ of the cube, until completing $360^{\circ}$, and performed 
8 repetitions of the analysis per sample of flour. The results were expressed by the average of these records using the CIE $\mathrm{L}^{\star} \mathrm{a}^{\star} \mathrm{b}^{\star}$ system of colour.

\subsection{Determination of the extraction yield and degree of esterification of pectin}

The pectin was extracted according to Fertonani et al. (2009). The flour was suspended (ratio 1:50 w/v) in $25 \mathrm{~mL}$ of distilled water added to $25 \mathrm{~mL}$ of nitric acid $1 \mathrm{~mol} \mathrm{~L}^{-1}$, previously warmed to $80^{\circ} \mathrm{C}$ in water bath (Precision Reciprocal Shaking Bath Model 50, Thermo Scientific, EUA), stirred for $40 \mathrm{~min}$ and cooled in ice bath. The solution was filtered and added to three volumes of ethanol, and then stored at $4{ }^{\circ} \mathrm{C}$ for $15 \mathrm{~h}$ (overnight). After centrifugation (Sorvall Legend RT Centrifuge, Thermo Scientific, EUA) at $4500 \mathrm{rpm}$ for 40 minutes, the pellet was added to cold acetone and newly centrifuged at $4500 \mathrm{rpm}$ for $20 \mathrm{~min}$. The pectin was dried in kiln with forced air at $37^{\circ} \mathrm{C}$ for $5 \mathrm{~h}$ and weighted in analytical balance. The result was expressed in relation to the mass of flour (dry basis), normalized to $100 \mathrm{~g}$.

The degree of esterification (DE) of pectin was determined according to Bochek et al. (2001). The mass of pectin $(0.2 \mathrm{~g})$ was wetted with $200 \mu \mathrm{L}$ of ethylic alcohol (95\%) and dissolved in $20 \mathrm{~mL}$ of distilled water using a homogenizer (Turratec TE 102, Tecnal, Brazil) operating at $1400 \mathrm{rpm}$ for 5 minutes. Residual insoluble pectin was filtered in synthetic tissue and dried to quantify only the mass of soluble pectin in solution. The amount (\%) of free carboxylic groups (FCG) was quantified by titration with $\mathrm{NaOH}$ $0.1 \mathrm{~mol} \mathrm{~L}^{-1}$ until $\mathrm{pH} 8.5$. The amount (\%) of esters linked to carboxylic group (LCG) was quantified after saponification with $10 \mathrm{~mL} \mathrm{NaOH} 0.1 \mathrm{~mol} \mathrm{~L}^{-1}$ stirred in shaker (Tecnal TE 420, Brazil) at $200 \mathrm{rpm}$ and $20^{\circ} \mathrm{C}$ for $2 \mathrm{~h}$. The solution was acidified with $10 \mathrm{ml} \mathrm{HCl} 0.1 \mathrm{~mol} \mathrm{~L}^{-1}$, and the excess of acidity was determined by titration until pH 8.5 to quantify the LCG. The DE (\%) was defined by the ratio LCG/(FCG+LCG).

\subsection{Statistical analysis}

The experiment was conducted in a completely randomized design (CRD). The Analysis of Variance (ANOVA) was used to determine the variation among samples of three maturation stages. It was evaluated the proportion in mass of the fruit components: rind fractions and crude pulp, with 80 replicates of fruits with the same pattern of size and shape. For physical and chemical analysis of the flours, each sample was composed by rind fractions of 8 fruits, with 10 replicates in each maturation stage. The endocarp flour was composed from 16 fruits due to the small amount of material, with 5 replicates per maturation stages. The data were compared by Tukey test at $\mathrm{p}<0.05$, using Statistical Analysis System - SAS, version 9.3 (SAS Statistical Analysis System, 2003).

\section{Results and discussions}

\subsection{Characterization of fruit maturation and pericarp fractions}

The fruits were classified as: clear green stage $(21.3 \pm 8 \%$ yellowish peel), intermediate stage $(56.7 \pm 12 \%$ yellowish peel) and ripe stage $(97.5 \pm 4 \%$ yellowish peel). These patterns of color correspond to the levels 3, 5 and 7, described by Silva et al. (2008).

The mass pattern of the fruits was similar in the different maturation stages (Table 1), with average of $251.1 \mathrm{~g}$, which is higher than that evaluated by Silva et al. (2015) for three maturation stages of passion fruits in the range of 182.4-195.4 g.

Nevertheless, the content of pulp was higher in the ripe fruits $(49.9 \%)$ in relation to green fruits $(45 \%)$. The increase in pulp content during the passion fruit ripening was also identified by Silva et al. (2008). The pulp content was lower in the 39 progenies of passion fruit investigated by Negreiros et al. (2008), with average of $35.6 \%$. However, the fruits were smaller, ranging from 92.0 to $179.6 \mathrm{~g}$, with average of $124.7 \mathrm{~g}$.

In contrast, Silva et al. (2015) found no influence of the maturation stages $(p>0.05)$ on length, equatorial diameter, length/equatorial diameter ratio, volume, weight, aryl, peel, pulp and seed yield, peel thickness, $\mathrm{pH}$, total soluble solids and vitamin $\mathrm{C}$.

The proportion of epicarp was similar in fruits of different maturation stages, with average of $13.7 \%$ (Table 1), which contrast to the average of $8.4 \%$ measured by Oliveira \& Resende (2012) in fruits at green maturation stages, but reaching $11.0 \%$ in ripe fruits.

In contrary, the proportion of endocarp increased from $3.2 \%$ in clear green fruits to $3.9 \%$ in ripe fruits, being the smaller fraction in the rind of passion fruit (Table 1).

Table 1. Proportion in mass ( $\mathrm{g} 100 \mathrm{~g}^{-1}$ fruit) of the rind components of yellow passion fruits at different maturation stages.

\begin{tabular}{|c|c|c|c|c|c|c|}
\hline \multirow{3}{*}{ Component } & \multicolumn{6}{|c|}{ Maturation Stages } \\
\hline & \multicolumn{2}{|c|}{ Clear green } & \multicolumn{2}{|c|}{ Intermediate } & \multicolumn{2}{|c|}{ Ripe } \\
\hline & $\begin{array}{c}\text { Mass }^{1} \\
(\mathrm{~g})\end{array}$ & $\begin{array}{c}\text { Proportion } \\
(\%)\end{array}$ & $\begin{array}{c}\text { Mass }^{1} \\
(\mathrm{~g})\end{array}$ & $\begin{array}{c}\text { Proportion } \\
(\%)\end{array}$ & $\begin{array}{c}\text { Mass }^{1} \\
(\mathrm{~g})\end{array}$ & $\begin{array}{c}\text { Proportion } \\
(\%)\end{array}$ \\
\hline Whole fruit & $253.4^{a} \pm 26.8$ & - & $248.8^{a} \pm 22.8$ & - & $251.1^{a} \pm 24.8$ & - \\
\hline Epicarp & $34.8^{a} \pm 6.3$ & 13.7 & $33.7^{\mathrm{a}} \pm 4.7$ & 13.5 & $34.7^{\mathrm{a}} \pm 6.5$ & 13.8 \\
\hline Endocarp & $8.1^{\mathrm{c}} \pm 1.2$ & 3.2 & $8.9^{\mathrm{b}} \pm 1.3$ & 3.6 & $9.9^{\mathrm{a}} \pm 2.5$ & 3.9 \\
\hline Mesocarp & $96.4^{\mathrm{a}} \pm 22.6$ & 38.0 & $86.4^{b} \pm 12.3$ & 34.7 & $81.2^{\mathrm{b}} \pm 14.4$ & 32.3 \\
\hline Crude pulp & $114.1^{\mathrm{b}} \pm 18.3$ & 45.0 & $119.7^{\mathrm{ab}} \pm 18.8$ & 48.1 & $125.2^{\mathrm{a}} \pm 16.6$ & 49.9 \\
\hline
\end{tabular}

${ }^{1}$ Average data are represented with respective standard deviation of 80 samples of fruits; Average values with equal letters in the same row do not differ by Tukey test at $\mathrm{P}<0.05$. 
The mesocarp fraction decreased among fruits of clear green stage $(38.0 \%)$ to intermediate stage $(34.7 \%)$ or ripe stage (32.3\%). Oliveira \& Resende (2012) also noted a decrease in mesocarp from $79.2 \%$ in green fruits to $39.1 \%$ in ripe fruits, however, presenting higher moisture (93.2\%) and lower content of pulp in green fruit, in contrast to this study, which presented lower moisture (Table 2). According to Negreiros et al. (2008), the passion fruits show high variability in mass of fruit or rind, but the sampling of eighty fruits is representative of infinite population in evaluations of physical characteristics, as observed by Coelho et al. (2011). The variability in the physical characteristics of passion fruits can reach $34.7 \%$ in different maturation stages (Silva et al., 2015).

\subsection{Determinations of apparent density of pericarp fractions}

Statistical analysis of the data showed that the epicarp has an apparent density of $1,013.7 \mathrm{~kg} \mathrm{~m}^{-3}$, differing significantly from the mesocarp fraction and the interface material between epicarp and mesocarp, which presented mean values of $877.9 \mathrm{~kg} \mathrm{~m}^{-3}$ and $923.5 \mathrm{~kg} \mathrm{~m}^{-3}$, respectively. The interface material presented a trend of higher density than the mesocarp fraction, denoting a change in the composition of the rind from the inner to the outer fraction of the pericarp. In fact, the differentiation of the tissue from mesocarp to epicarp fraction is more notable in ripe fruits, as indicated by their white and yellow tissue colors, respectively. However, in an unripe fruit the interface material is characterized by greener color.

The evaluation of the results indicated that the epicarp fraction has higher density than mesocarp fraction, thus allowing their separations after rind crushing and suspension in a water floating system, since the epicarp can be decanted in slow water flow, whereas the mesocarp can be separated by flotation.

\subsection{Characterization of yield and color of rind flour and pectin}

The yield of flour of epicarp and mesocarp did not change in the three maturation stages of the fruit, with averages of $3.4 \%$ and $4.6 \%$, respectively (Table 2). This result is similar to that found by Oliveira \& Resende (2012) for the mesocarp flour
(3.9\%), but with a higher content of initial moisture. In contrast, the yield of endocarp flour increased from $0.45 \%$ (clear green stage) to $0.60 \%$ in ripe fruits, thus denoting accumulation of dry matter in the endocarp, since the moisture remained constant.

The final moisture content was higher in the mesocarp flour due to the higher thickness of the raw material during the drying process, mainly when comparing the fractions of mesocarp and endocarp with similar contents of initial moisture. Moreover, the initial moisture of the mesocarp was lower in ripe fruits, as also noted by Oliveira \& Resende (2012).

The colors of the flours were differentiated for the three components of the rind (Table 2). The luminosity $\left(\mathrm{CIE} \mathrm{L}^{*}\right)$ was lower for the epicarp flour, but without differences among the maturation stages, as also it can be noted for the flour of mesocarp, which, however, presented the highest luminosity. The endocarp flour increased its luminosity in ripe fruits, although with lower value than the mesocarp flour. The yellowish pattern of color $\left(\mathrm{CIE} \mathrm{b}^{\star}\right.$ ) was equal in mesocarp flour of the three maturation stages, also being clearer than the epicarp flour. The increase in the yellowish color of the endocarp flour may be due to the accumulation of carotenoid compounds (Mercadante et al., 1998). On the contrary, the greenish index $\left(\mathrm{CIE} \mathrm{a}^{\star}\right)$ was prominent in the epicarp flour of the green fruit, but the mesocarp flour did not present greenish color pattern at the green stage, being of homogeneous neutral color for all maturation stages.

In flour of crude rind of passion fruit, Leoro (2007) found a lower luminosity $\left(\mathrm{CIE} \mathrm{L}^{*}=72.3\right)$, a lower value of yellowish color $\left(\mathrm{CIE} \mathrm{b}^{\star}=20.8\right)$ and a higher gray red tonality $\left(\mathrm{CIE} \mathrm{a}^{\star}=4.8\right)$, in comparison to the flour of mesocarp removed from the rind and evaluated in this study.

The yield of pectin extraction had great differentiation for the three components of the rind (Table 3). A decrease in the content of pectin was noticed in the epicarp flour of green fruits (16.7\%) until the ripe stage (13.3\%). The endocarp flour presented the lowest content of pectin in fruits of ripe stage (2.7\%). Regarding the mesocarp flour, the content of pectin did not change in the maturation stages, with an average of $26.6 \%$. This result was similar to the one found by Oliveira \& Resende (2012), with $26.4 \%$ of pectin. The extraction yield and quality

Table 2. Characterization of moisture content, color parameters CIE L* $a^{\star} b^{\star}$, yield of flour from components of the rind of yellow passion fruits at different maturation stages.

\begin{tabular}{|c|c|c|c|c|c|c|c|}
\hline \multirow{2}{*}{ Rind fraction } & \multirow{2}{*}{$\begin{array}{c}\text { Maturation } \\
\text { stages }\end{array}$} & \multicolumn{2}{|c|}{ Moisture content $(\%)^{1}$} & \multicolumn{3}{|c|}{ Instrumental color $^{1}$} & \multirow{2}{*}{$\begin{array}{c}\text { Yield }(\%) \\
\text { YF } \\
\end{array}$} \\
\hline & & $\mathrm{BD}$ & $\mathrm{AD}$ & $\mathrm{L}^{*}$ & $\mathrm{a}^{*}$ & $\mathrm{~b}^{*}$ & \\
\hline \multirow{3}{*}{ Epicarp } & Clear green & $77.6^{\mathrm{a}} \pm 1.9$ & $12.7^{\mathrm{a}} \pm 1.2$ & $72.56^{\mathrm{a}} \pm 1.4$ & $-0.45^{c} \pm 1.1$ & $28.28^{a} \pm 0.9$ & $3.46^{\mathrm{a}} \pm 0.6$ \\
\hline & Intermediate & $78.4^{\mathrm{a}} \pm 2.1$ & $10.6^{\mathrm{b}} \pm 1.4$ & $73.59^{\mathrm{a} \pm} 1.0$ & $0.94^{\mathrm{b}} \pm 0.7$ & $27.94^{\mathrm{a}} \pm 0.7$ & $3.31^{\mathrm{a}} \pm 0.5$ \\
\hline & ripe & $78.2^{\mathrm{a}} \pm 2.3$ & $10.5^{\mathrm{b}} \pm 0.8$ & $72.30^{\mathrm{a}} \pm 0.7$ & $3.21^{\mathrm{a}} \pm 0.3$ & $27.66^{\mathrm{a}} \pm 0.5$ & $3.45^{\mathrm{a}} \pm 0.7$ \\
\hline \multirow[b]{2}{*}{ Mesocarp } & Clear green & $89.0^{\mathrm{a}} \pm 0.5$ & $19.9^{\mathrm{a}} \pm 1.9$ & $81.10^{\mathrm{a}} \pm 0.9$ & $2.54^{\mathrm{a}} \pm 0.4$ & $24.54^{\mathrm{a}} \pm 0.8$ & $4.66^{\mathrm{a}} \pm 0.8$ \\
\hline & Intermediate & $88.5^{\mathrm{a}} \pm 0.6$ & $18.1^{\mathrm{b}} \pm 1.2$ & $81.88^{\mathrm{a}} \pm 1.3$ & $2.74^{\mathrm{a}} \pm 0.4$ & $24.33^{\mathrm{a}} \pm 0.8$ & $4.60^{\mathrm{a}} \pm 0.9$ \\
\hline \multirow[t]{2}{*}{ Endocarp } & Intermediate & $87.3^{\mathrm{a}} \pm 1.5$ & $11.5^{\mathrm{a}} \pm 1.0$ & $78.42^{\mathrm{b}} \pm 1.5$ & $4.22^{\mathrm{a}} \pm 0.7$ & $28.94^{\mathrm{b}} \pm 1.6$ & $0.51^{\mathrm{b}} \pm 0.1$ \\
\hline & ripe & $86.6^{\mathrm{a}} \pm 0.5$ & $11.5^{\mathrm{a}} \pm 0.8$ & $80.88^{\mathrm{a}} \pm 0.3$ & $2.79^{\mathrm{b}} \pm 0.3$ & $31.03^{\mathrm{a}} \pm 0.6$ & $0.60^{\mathrm{a}} \pm 0.1$ \\
\hline
\end{tabular}

${ }^{1}$ Averages with equal letters in the same column for each of the rind fraction do not differ by Tukey test at $\mathrm{P}<0.05$; Average data are represented with respective standard deviation; BD: Initial moisture before drying $\left(\mathrm{g} 100 \mathrm{~g}^{-1}\right) ; \mathrm{AD}$ : Moisture after drying $\left(\mathrm{g} 100 \mathrm{~g}^{-1}\right) ; \mathrm{L}^{*}$ : luminosity, $\mathrm{L}^{*}=0$, black; $\mathrm{L}^{*}=100$, white; $\mathrm{a}^{*}>0$, red; $\mathrm{a}^{*}<0$, green; $\mathrm{b}^{*}>0$, yellow; $\mathrm{b}^{*}<0$, blue; YF: Yield of flour (\%) with 10\% Moisture. 
Table 3. Characterization of yield of extraction and esterification degree of pectin from components of the rind of yellow passion fruits at different maturation stages.

\begin{tabular}{|c|c|c|c|c|c|}
\hline \multirow{2}{*}{ Rind fraction } & \multirow{2}{*}{ Maturation stages } & \multicolumn{3}{|c|}{ Pectin } & \multirow{2}{*}{$\begin{array}{c}\text { Yield (\%) } \\
\mathrm{YP}^{1}\end{array}$} \\
\hline & & $\mathrm{DE}^{1}$ & $\mathrm{FCG}^{1}$ & $\mathrm{LCG}^{1}$ & \\
\hline \multirow{4}{*}{ Epicarp } & Clear green & $59.5^{\mathrm{a}} \pm 1.0$ & $14.6^{\mathrm{a}} \pm 2.3$ & $21.4^{\mathrm{a}} \pm 3.6$ & $16.7^{\mathrm{a}} \pm 0.8$ \\
\hline & Intermediate & $52.5^{\mathrm{b}} \pm 1.0$ & $14.0^{\mathrm{a}} \pm 1.1$ & $15.5^{\mathrm{b}} \pm 1.5$ & $13.9^{\mathrm{b}} \pm 1.5$ \\
\hline & ripe & $49.9^{c} \pm 1.2$ & $16.0^{\mathrm{a}} \pm 1.3$ & $15.9^{\mathrm{b}} \pm 1.4$ & $12.6^{\mathrm{b}} \pm 0.7$ \\
\hline & Clear green & $49.8^{\mathrm{c}} \pm 1.0$ & $18.1^{\mathrm{a}} \pm 1.8$ & $17.9^{\mathrm{b}} \pm 1.9$ & $27.7^{\mathrm{a}} \pm 0.9$ \\
\hline \multirow[t]{2}{*}{ Mesocarp } & Intermediate & $56.4^{\mathrm{b}} \pm 1.4$ & $14.3^{\mathrm{b}} \pm 2.0$ & $18.6^{\mathrm{b}} \pm 2.9$ & $26.7^{\mathrm{a}} \pm 1.0$ \\
\hline & ripe & $76.3^{\mathrm{a}} \pm 1.5$ & $16.1^{\mathrm{ab}} \pm 1.1$ & $52.3^{\mathrm{a}} \pm 5.2$ & $25.5^{\mathrm{a}} \pm 2.0$ \\
\hline \multirow{3}{*}{ Endocarp } & Clear green & $49.0^{c} \pm 2.4$ & $17.5^{\mathrm{a}} \pm 2.8$ & $16.9^{\mathrm{a}} \pm 3.1$ & $6.7^{\mathrm{a}} \pm 1.9$ \\
\hline & Intermediate & $55.2^{\mathrm{b}} \pm 0.9$ & $13.4^{\mathrm{b}} \pm 1.1$ & $16.5^{\mathrm{a}} \pm 1.4$ & $4.2^{\mathrm{b}} \pm 1.9$ \\
\hline & ripe & $69.5^{\mathrm{a}} \pm 0.8$ & $7.8^{c} \pm 1.7$ & $17.7^{\mathrm{a}} \pm 3.7$ & $2.7^{c} \pm 1.9$ \\
\hline
\end{tabular}

${ }^{1}$ Averages with equal letters in the same column for each of the rind fraction do not differ by Tukey test at $\mathrm{P}<0.05$; Average data are represented with respective standard deviation; YP: Yield of pectin (\%); DE: Degree of Esterification of pectin (\%); FCG: Free carboxylic groups (\%); LCG: Carboxylic groups linked to esters (\%).

of the pectin is influenced by the time of extraction, the kind of acid, $\mathrm{pH}$, temperature of the medium and proportion of material in suspension (Kulkarni \& Vijayanand, 2010; Sundarraj \& Ranganathan, 2017).

The content of pectin varies among the different sources of raw material, with focus on orange mesocarp - 20\% (Fishman et al., 2000 ), mangoes - $18 \%$ (Berardini et al., 2005), apple pomace - 15\% (Fertonani et al., 2009). In the flour of epicarp, mesocarp and bagasse of Tahiti lemon, the pectin contents were 12.8\%, 22.8\% and $18.9 \%$, respectively (Mendonça et al., 2006). The amount of pectin extracted from orange peel and lemon peels on fresh basis was $15.25 \%$ and $20.75 \%$, respectively (Sulieman et al., 2013).

The content of pectin in different fractions of passion fruit pericarp was evaluated by Canteri et al. (2010b). The exocarp (epicarp) and endocarp flours presented the lowest values, with $5.3 \%$ and $5.8 \%$, respectively, differing from the mesocarp flour with $13 \%$ of pectin. These results are far lower than those found in the present study, but the higher content of pectin in mesocarp flour was confirmed in both researches. The higher content of pectin may be due to the double time of extraction (40 min) and the higher concentration of the nitric acid used in the present study, as compared to the research done by the former researchers. Another important difference between both researches is that, in the present research, the rind fractions of the fruits were evaluated in selected conditions of maturation stage, whereas, in the former investigation, the fruit maturation was not well standardized and it may have presented higher variability. It is also emphasized that, on the contrary of the former studies, the endocarp flour presented the lowest content of pectin, along with a decrease of pectin in the endocarp flour of ripe fruit.

The degree of esterification (DE) of pectin also presented great difference between the three components of the rind (Table 3). In the epicarp flour, it decreased from $59.5 \%$ in clear green fruit to $49.9 \%$ in ripe fruits $(49.9 \%)$. In contrast, it increased from $49.8 \%$ in mesocarp flour of clear green fruit to $76.3 \%$ in ripe fruits. It also increased in endocarp flour. The native pectin is generally of high esterification degree and low acetylation degree (Ralet et al., 2003). However, there are plants with pectin of low degree of esterification that change to high metoxilation degree (Iglesias \& Lozano, 2004).

In this research, the pectin of the mesocarp flour of ripe fruits is considered as of high degree of esterification, as it was also noted in the study of D'Addosio et al. (2005), with DE equal to $69.7 \%$. When comparing the three fractions of passion fruit rind, Canteri et al. (2010b) found higher value of DE in mesocarp flour (79\%) followed by DE 70\% in epicarp flour and 59\% in endocarp flour. In the present study, it was verified a change in $\mathrm{DE}$ of pectin, as a function of the maturation stages of the passion fruit, in which the highest value of $\mathrm{DE}$ was found in mesocarp flour of ripe fruits. The same behavior was found for the endocarp flour, which increased its DE from $49 \%$ in green fruits to $69.5 \%$ in ripe fruits, in contrast to the epicarp flour that decreased its DE from $59.5 \%$ (green fruits) to $49.9 \%$ in ripe fruits.

The procedure for extraction has great influence on physicochemical and molecular structure of pectin, as well as it can change its gelling capacity (Canteri et al., 2010b; Kulkarni \& Vijayanand, 2010). The higher yield of pectin is achieved with higher concentrations of acid, time and temperature of extraction. Nevertheless, these factors may promote damages in the molecule of pectin, hindering its gelling capacity (Yapo, 2009).

\section{Conclusions}

This research achieves a result about the importance of using the mesocarp fraction of the passion fruit rind to produce clearer flour with higher content of pectin. Its color pattern and content of pectin did not change with the maturation stage of the fruits, but the DE of pectin increases deeply from low $\mathrm{DE}$ in green fruits to high $\mathrm{DE}$ in ripe fruits.

Despite its lowest yield of flour ( $0.6 \%$ in ripe fruits), the endocarp flour may be blended with the mesocarp flour of ripe fruits (4.6\% yield of flour), once both present quite similar patterns of color and DE of pectin. On the contrary to the epicarp flour (3.5\% yield of flour), that must not be blended to the mesocarp flour due to its brownish color and low $\mathrm{DE}$ of pectin in ripe fruits.

The mesocarp with the lowest apparent density can be separated from the epicarp after rind crushing and suspension in 
water floating system, since the epicarp can be decanted in a slow water flow, whereas the mesocarp can be separated by flotation.

\section{Acknowledgements}

The authors gratefully acknowledge the financial support and the research grants provided by Fundação de Amparo à Pesquisa do Estado do Rio de Janeiro - FAPERJ (Brazil), Coordenação de Aperfeiçoamento de Pessoal de Nível Superior - CAPES (Brazil) and Conselho Nacional de Desenvolvimento Científico e Tecnológico - CNPq (Brazil), and Mr. José Roberto (passion fruit producer) for supplying the raw material

\section{References}

Araújo, M. F. M., Veras, V. S., Freitas, R. W. J. F., Paula, M. L., Araújo, T. M., Uchôa, L. R. A., Gaspar, M. W. G., Cunha, M. C. S. O., Serra, M. A. A. O., Carvalho, C. M. L., Costa, E. C., \& Damasceno, M. M. C. (2017). The effect of flour from the rind of the yellow passion fruit on glycemic control of people with diabetes mellitus type 2: a randomized clinical trial. Journal of Diabetes and Metabolic Disorders, 17, 1-7. PMid:28428951.

Association of Official Analytical Chemists - AOAC. (1990). Official methods of analysis of the Association of Official Analytical Chemists (15th ed. Vol. 2, Method 925.23, 945.46). Arlington: AOAC.

Berardini, N., Knödler, M., Schieber, A., \& Carle, R. (2005). Utilization of mango peels as a source of pectin and polyphenolics. Innovative Food Science \& Emerging Technologies, 6(4), 442-452. http://dx.doi. org/10.1016/j.ifset.2005.06.004.

Bochek, A. M., Zabivalova, N. M., \& Petropavlosvskii, G. A. (2001). Determination of the esterification degree of polygalacturonic acid. Russian Journal of Applied Chemistry, 74, 775-777.

Canteri, M. H. G., Scheer, A. P., Wosiacki, G., Ginies, C., Reich, M., \& Renard, C. M. C. G. (2010a). A comparative study of pectin extracted from passion fruit rind flours. Journal of Polymers and the Environment, 18(4), 593-599. http://dx.doi.org/10.1007/s10924010-0206-z.

Canteri, M. H. G., Scheer, A. P., Petkowicz, C., Ginies, C., Renard, C. M. C. G., \& Wosiacki, G. (2010b). Physicochemical composition of the yellow passion fruit pericarp fractions and respective pectic substances. Journal of Food and Nutrition Research, 49, 113-122.

Claro, M. L., Rodrigues, G. P., \& Teixeira, S. A. (2018). Functional properties of yellow passion fruit bark (Passiflora edulis) in metabolic syndrome. Demetra: Food. Nutrition and Health (Berkhamsted, Hertfordshire), 13(1), 181-194.

Coelho, A. A., Oliveira, E. M. S., Resende, E. D., \& Thiébaut, J. T. L. (2011). Sample size for postharvest quality characterization of yellow passion fruits. Revista Ceres, 58, 23-28. http://dx.doi.org/10.1590/ S0034-737X2011000100004.

Conti-Silva, A. C., \& Roncari, R. F. (2015). Sensory features and physical-chemical characterization of Brazilian honey bread with passion fruit peel flour. Nutrition \& Food Science, 45(4), 595-605. http://dx.doi.org/10.1108/NFS-03-2015-0023.

D’Addosio, R., Páez, G., Marín, M., Mármol, Z., \& Ferrer, J. (2005). Obtención y caracterización de pectina a partir de La cáscara de parchita (Passiflora edulis f. flavicarpa Degener). Revista de la Facultad de Agronomía, 22, 240-249. [LUZ]

Espírito Santo, A. P., Perego, P., Converti, A., \& Oliveira, M. N. (2012). Influence of milk type and addition of passion fruit peel powder on fermentation kinetics, texture profile and bacterial viability in probiotic yoghurts. Lebensmittel-Wissenschaft + Technologie, 47(2), 393-399. http://dx.doi.org/10.1016/j.lwt.2012.01.038.

Fertonani, H. C. R., Scabio, A., Carneiro, E. B. B., Schemim, M. H. C., Nogueira, A., \& Wosiacki, G. (2009). Extraction model of low methoxyl pectin from apple pomace: effects of acid concentration and time on the process and the product. Brazilian Archives of Biology and Technology, 52(1), 177-185. http://dx.doi.org/10.1590/ S1516-89132009000100023.

Figueiredo, D. A. F., Pordeus, L. C. M., Paulo, L. L., Braga, R. M., Fonsêca, D. V., Sousa, B. S., Costa, M. J. C., Gonçalves, M. C. R., \& Oliveira, K. H. D. (2016). Effects of bark flour of Passiflora edulis on food intake, body weight and behavioral response of rats. Braz J Phamacogn, 26(5), 595-600. http://dx.doi.org/10.1016/j.bjp.2016.02.010.

Fishman, M. L., Chau, H. K., Hoagland, P., \& Ayyad, K. (2000). Characterization of pectin, flash-extracted from orange albedo by microwave heating, under pressure. Carbohydrate Research, 323(14), 126-138. http://dx.doi.org/10.1016/S0008-6215(99)00244-X. PMid:10782294.

Gubiani, P. I., Reinert, D. J., \& Reichert, J. M. (2006). Alternative method to measure the soil particle density - exactness, precision, and processing time. Ciência Rural, 36(2), 664-668. http://dx.doi. org/10.1590/S0103-84782006000200049.

Iglesias, M. T., \& Lozano, J. E. (2004). Extraction and characterization of sunflower pectin. Journal of Food Engineering, 62(3), 215-223. http://dx.doi.org/10.1016/S0260-8774(03)00234-6.

Instituto Brasileiro de Geografia e Estatística - IBGE. (2017). Produção agrícola municipal. Retrieved from http://www.sidra.ibge.gov.br/ bda/tabela/listabl.asp? $\mathrm{z}=\mathrm{t} \& \mathrm{c}=1613$

Kulkarni, S. G., \& Vijayanand, P. (2010). Effect of extraction conditions on the quality characteristics of pectin from passion fruit peel (Passiflora edulis f. flavicarpa L.). Lebensmittel-Wissenschaft + Technologie, 43(7), 1026-1031. http://dx.doi.org/10.1016/j.lwt.2009.11.006.

Leoro, M. G. V. (2007). Desenvolvimento de cereal matinal extrusado orgânico à base de farinha de milho e farelo de maracujá (Dissertação de mestrado). Universidade Estadual de Campinas, Campinas.

López-Vargas, J. H., Fernández-López, J. F., Pérez-Álvarez, J. A., \& Viuda-Martos, M. (2013). Chemical, physico-chemical, technological, antibacterial and antioxidant properties of dietary fiber powder obtained from yellow passion fruit (Passiflora edulis var. flavicarpa) co-products. Food Research International, 51(2), 756-763. http:// dx.doi.org/10.1016/j.foodres.2013.01.055.

López-Vargas, J. H., Fernández-López, J., Pérez-Álvarez, J. Á., \& ViudaMartos, M. (2014). Quality characteristics of pork burger added with albedo-fiber powder obtained from yellow passion fruit (Passiflora edulis var. flavicarpa) co-products. Meat Science, 97(2), 270-276. http://dx.doi.org/10.1016/j.meatsci.2014.02.010. PMid:24607997.

Marques, S. S. F., Libonati, R. M. F., Sabaa-Srur, A. U. O., Luo, R., Shejwalkar, P., Hara, K., Dobbs, T., \& Smith, R. E. (2016). Evaluation of the effects of passion fruit peel flour (Passiflora edulis fo. flavicarpa) on metabolic changes in HIV patients with lipodystrophy syndrome secondary to antiretroviral therapy. Braz J Pharmacogn, 26(4), 420426. http://dx.doi.org/10.1016/j.bjp.2016.03.002.

Mendonça, L. M. V. L., Conceição, A., Piedade, J., Carvalho, V. D., \& Theodoro, V. C. A. (2006). Chemical composition and Tahiti lime industrial residues output characterization. Food Science and Technology (Campinas), 26, 870-874.

Mercadante, A. Z., Britton, G., \& Rodriguez-Amaya, D. B. (1998). Carotenoids from Yellow Passion Fruit (Passiflora edulis). Journal of Agricultural and Food Chemistry, 46(10), 4102-4106. http://dx.doi. org/10.1021/jf9801724.

Nascimento, E. M. G. C., Ascheri, J. L. R., Carvalho, C. W. P., \& Galdeano, M. C. (2013). Benefits and risks of using passion fruit 
peel (Passiflora edulis) as an ingredient in food production. Revista do Instituto Adolfo Lutz, 72, 1-11.

Negreiros, J. R. S., Araújo, S. E., No., Álvares, V. S., Lima, V. A., \& Oliveira, T. K. (2008). Physicochemical characteristics of fruits of progenies of yellow passion fruit tree half-sib in Rio Branco - Acre. Revista Brasileira de Fruticultura, 30(2), 431-437. http://dx.doi. org/10.1590/S0100-29452008000200028.

Oliveira, E. M. S., \& Resende, E. D. (2012). Yield of flour and pectin in the rind of yellow passion fruit. Food Science and Technology (Campinas), 32, 492-498. http://dx.doi.org/10.1590/S0101-20612012005000067.

Pimentel, L. D., Santos, C. E. M., Ferreira, A. C. C., Martins, A. A., Wagner, A., Jr., \& Bruckner, C. H. (2009). Cost of production and profitability of the passion fruit plant in the agroindustrial market of the Zona da Mata of Minas Gerais State, Brazil. Revista Brasileira de Fruticultura, 31(2), 397-407. http://dx.doi.org/10.1590/S010029452009000200013.

Quirós-Sauceda, A. E., Palafox-Carlos, H., Sáyago-Ayerdi, S. G., AyalaZavala, J. F., Bello-Perez, L. A., Alvarez-Parrilla, E., de la Rosa, L. A., González-Córdova, A. F., \& González-Aguilar, G. A. (2014). Dietary fiber and phenolic compounds as functional ingredients: interaction and possible effect after ingestion. Food \& Function, 5(6), 1063-1072. http://dx.doi.org/10.1039/C4FO00073K. PMid:24740575.

Ralet, M.-C., Crépeau, M.-J., Buchholt, H.-C., \& Thibault, J.-F. (2003). Polyelectrolyte behaviour and calcium binding properties of sugar beet pectins differing in their degrees of methylation and acetylation. Biochemical Engineering Journal, 16(2), 191-201. http://dx.doi. org/10.1016/S1369-703X(03)00037-8.

SAS Statistical Analysis System - SAS. (2003). SAS user's guide. USA: SAS Institute Inc.

Silva, M A P., C, C., Caliari, M., Carvalho, B. S., Placido, G. R., Silva, R. M., Soares, J. C., Lima, M. S., Araujo, V F P., \& Carmo, R. M.
(2015). Physical and chemical characteristics and instrumental color parameters of passion fruit (Passiflora edulis Sims). African Journal of Agricultural Research, 10(45), 4142-4149. http://dx.doi. org/10.5897/AJAR2015.9682.

Silva, T. V., Resende, E. D., Viana, A. P., Pereira, S. M. F., Carlos, L. A., \& Vitorazi, L. (2008). Determination of the peel color scale and juice yield of yellow passion fruits in different harvest seasons. Revista Brasileira de Fruticultura, 30(4), 880-884. http://dx.doi.org/10.1590/ S0100-29452008000400007.

Smith, R. E., Menezes, E. M. S., Sabaa-Srurc, A. U. O., \& Wycoff, W. (2012). Potential health benefits of passion fruit peel flour. The Natural Products Journal, 2, 104-107. http://dx.doi.org/10.2174/2 210315511202020104.

Sulieman, A. M. E., Kawther, M. Y. K., \& Zakaria, A. S. (2013). Extraction of Pectin from Lemon and Orange Fruits Peels and Its Utilization in Jam Making. Intern. J. Food Sci. and Nutri. Engg., 3(5), 81-84.

Sundarraj, A. A., \& Ranganathan, T. V. (2017). A Review - Pectin from Agro and Industrial Waste. International Journal of Applied Environmental Sciences, 12, 1777-1801.

Tseng, A., \& Zhao, Y. (2013). Wine grape pomace as antioxidant dietary fibre for enhancing nutritional value and improving storability of yogurt and salad dressing. Food Chemistry, 138(1), 356-365. http:// dx.doi.org/10.1016/j.foodchem.2012.09.148. PMid:23265499.

Vasco-Correa, J., \& Zapata, A. D. Z. (2017). Enzymatic extraction of pectin from passion fruit peel (Passiflora edulis f. flavicarpa) at laboratory and bench scale. Lebensmittel-Wissenschaft + Technologie, 80, 280-285. http://dx.doi.org/10.1016/j.lwt.2017.02.024.

Yapo, B. M. (2009). Biochemical characteristics and gelling capacity of pectin from yellow passion fruit rind as affected by acid extractant nature. Journal of Agricultural and Food Chemistry, 57(4), 1572-1578. http://dx.doi.org/10.1021/jf802969m. PMid:19199593. 